\title{
With the Implementation of Curriculum Design of Web Network Based on the Teaching of Japanese Intensive Reading
}

\author{
Shuang Zheng \\ \{zhengshaung@163.com\} \\ Department of Foreign Languages Hanjiang Normal University, Shiyan 442000, China
}

\begin{abstract}
This paper discusses the course of the development of Japanese teaching, focusing on the domestic on the Japanese network teaching, computer assisted language teaching research, summed up the process of the development of Japanese Teaching: the development of computer technology makes Japanese Teaching in teaching methods through the computer auxiliary help prepare lessons, multimedia technology assisted teaching and multimedia courseware assisted teaching process, and the popularity of the Internet to Japanese teaching provides rich network of learning resources and convenient platform for the exchange. And the development of the Japanese network teaching is the combination of the three. Author basis at home and abroad on the design of network course teaching evaluation criteria, in the way of questionnaire, the network college Japanese intensive reading course design were present situation investigation, clarify the Japanese network teaching curriculum design, there exist the following problems: courses column is arranged on the guiding function to study need to be improved; courseware presentation quality, learning and control the course of navigation design to the students' learning inconvenience. On the basis of foreign language teaching, network teaching of instructional design theory, from the curriculum program, learning content and courseware quality of existing Japanese intensive reading the first volume of network teaching course design is improved. The trial of Japanese major students shows that the improvement can stimulate students' learning interest and promote the learning of Japanese.
\end{abstract}

Keywords: Network teaching; curriculum design; online learning; system design

\section{Introduction}

Compared with the traditional classroom teaching, network teaching to allow participation in network education, teachers and students to great degree of freedom and autonomy, to achieve anytime, anywhere to learn and exchange, and is not influenced by the time and space constraints of traditional classroom teaching, this is a great place to the those because of work, body and so on unable to participate in the traditional school education, as they provide an opportunity for education [1]. This for our country at this stage of education resources, particularly in the allocation of higher education resources seriously uneven situation, network education is undoubtedly solution of higher education should not only quality but also the contradiction, to achieve "education for all without discrimination", lifelong learning is a way out. However, the existing exploration of the Japanese network 
teaching mainly limited to the network teaching is a useful supplement to the traditional classroom teaching and most of them only relates to the design and development of courseware, and did not form a strict sense network curriculum design theory system. For the Japanese Intensive Reading Course Design Network Teaching in the field, also need to be explored and researched. In recent years, researchers for the design and development of the role of the application of computers in language teaching and learning, network in learning Japanese, computer assisted language teaching courseware were studied some progress has been made. At the same time, teachers of the Japanese network teaching curriculum design are explored, although in a far cry from the study of the number and influence with English network teaching design, but also reflects the teaching design idea gradually thorough Japanese traditional classroom teaching and Japanese field of network teaching. Hunan University School of foreign languages Li Dali and Hetao complete cooperation "papers on computer in Japanese teaching application", this paper pointed out that current Japanese teaching development is swift and violent, but a serious shortage of teachers, teaching materials is uneven, the curriculum is unable to meet the needs of daily teaching. Although audio-visual equipment in Japanese teaching has been widely used to enhance the students' learning interest, improve the learning effect, but students can not communicate with them. The author points out that it is feasible and necessary to introduce computer into teaching [2].

For teachers, the computer can reduce the repetitive work of teachers, the teachers from the heavy homework and the preparation of papers and other documents to work out, and improve the students' guidance for the. For students, the computer provides man-machine dialogue can enable students to practise speaking, with notes of a computer system is easy to keep and finishing, provide computer dictionary can be learning to provide help if the network can also be used for remote communication. In addition, proficiency in the use of computers is also easy to facilitate the smooth employment of Japanese professional students. Northeast Normal University Department of Educational Technology Master Peng Qi dissertation based on the intensive network of multimedia assisted language teaching courseware design and development ", the first analysis of the network era Japanese in the direction of development to strengthen the teaching. With the development of Japanese teaching, situational language teaching also has been paid more and more attention, and in the teaching using multimedia assisted teaching system can easily show the perceptual material and create the best situation, so as to obtain the best teaching effect. The China's visit to Japan to study short-term Japanese preparatory school students strengthen education network courseware as an example, the intensifying Japanese language teaching courseware development should be on the basis of behaviorism theory, construction theory, situated cognition theory and the system science theory, and follow the teaching principle of subsidiary, establishment of information database principle, the interface simple and use convenient principle, purpose, principle, overall principle, subject principle, audio-visual and thinking combined with the principle, the media selection and combination optimization principle and timely and accurate feedback principle. The article also talked about the software development tools (that is, the development of software), the definition and classification of courseware, the characteristics of Japanese teaching. 


\section{System Status Analysis}

Instructional design, which refers to the teaching objectives, teaching process and teaching evaluation methods of reasonable design, which is the key to determine the quality of the network courses, network courses are different from the general characteristics of the network software. The curriculum teaching design is good, the teaching function is complete, in the study goal, the teaching process and the strategy as well as the study appraisal and so on are the design reasonable, can contribute to the effective study. This dimension includes 14 indexes: learning goal, goal level, learner control, content interaction, communication and collaboration, motivation interest, knowledge introduction, media selection practice feedback, tracking evaluation, result evaluation. The specification from the four dimensions of the course content, the teaching design, interface design and technology to evaluate the quality characteristics of network course, suitable for in network course of survival in the quality evaluation, including in the different stages of design, development, transport and use of curriculum resources on the network to the order of evaluation and final evaluation. Each dimension contains a specific evaluation indicators, the entire specification includes 36 indicators [3].

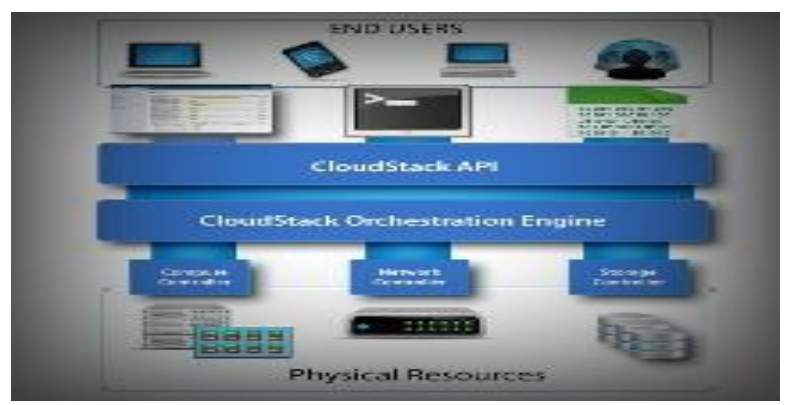

Fig. 1. Schematic diagram of the system cloud platform

\subsection{Frame Structure Design}

Online education excellent courses is with first-class teachers, first-class teaching content, first-class teaching methods, first-class resources and teaching materials, first-class teaching management and support services, characteristics and network education characteristics of the demonstration course. To reflect application type talents training target, in line with the direction of scientific, advanced and the rules of network education and teaching reform, suitable for on-the-job employees amateur learning and lifelong learning, and can be a proper use of modern education technology services in place, significant teaching effect, with demonstration, radiation and sharing. Writing Xia Jianxue Nanyang Normal University Institute of foreign languages of the the use of multimedia teaching of Japanese first talked about the definition of multimedia. Then, author mentioned the use of multimedia teaching Japanese have the following advantages: helps to stimulate students' learning motivation; is helpful to the cultivation of communication ability; the individualized teaching possible; can achieve infinite repeated practice, makes it possible for the distance education. Then, the author discusses the feasibility of Japanese teaching with Multimedia: hardware, peopleware (Master of computer technology more and more foreign language teachers) and software (courseware making tools more intelligent, simple) these three factors. At the same time, the 
author also points out that the problems existed in the teaching of multimedia applications: information capacity of the courseware and teaching issues speed, courseware art forms, the courseware materials advanced problems and teaching equipment costs [4].

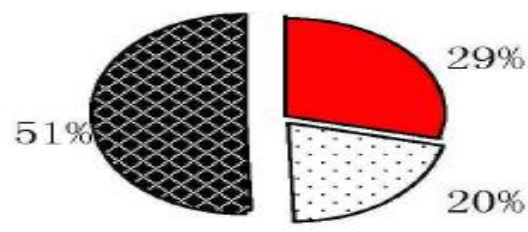

Fig. 2. Students' evaluation of courseware navigation design

The theory of behavior has a profound influence on the study, especially on the foreign language learning. Among them, the "stimulus response" theory proposed by Skinner in the forty or fifty's of last century is the most important one in the theory of behavior. Skinner believes that human thinking is the result of interaction with the external environment, that is, "stimulus - response", the link between stimulus and response is to strengthen. According to the "operation" of the environment and the "positive reinforcement" of the behavior, any action can be created and changed. Due to the emphasis on the environment of the "operation", Skinner's theory is also known as the theory of operating conditions. It is believed that learning should be a small step, a self paced, a positive response, and a timely reinforcement. These theories have important implications for the design of network courseware. The situational teaching of foreign language is based on the theory of situational awareness, and the teaching content, the role and the scene are highly integrated. In the network teaching practice of each foreign language teaching, it is the core of the curriculum design to effectively fuse the teaching content and create the realistic situation. Characteristics of the learners, including age, gender, cognitive differences, emotional factors and personality. The learning process is composed of the strategies and methods adopted by the learners and the less explicit conscious and unconscious mental activity. People are basically divided into two kinds of learning conditions, which are the target language environment and the target language environment. Learning conditions and learning styles are influenced by the social environment. Effects of foreign language learning factors, relationship between the understanding of these basic factors, contribute to a better understanding of the nature of foreign language learning, so as to successfully for curriculum design of the network teaching in Japanese laid a solid theoretical foundation.

\section{Design and Implementation of the System}

The original learning goal column lists the learning goals of each unit. But the author believes that this approach is not conducive to the teaching objectives and teaching content is not conducive to highlight the role of learning objectives, is not conducive to guiding students to carry out specific unit of learning. Curriculum column adjustment will be the overall learning objectives of the curriculum in the course introduction part, and for each unit of 
learning to develop a detailed unit goal (that is, behavioral goals). Unit learning objectives are placed in the learning content of each unit. A clear understanding of the learning objectives of each unit can help students to learn the course content better and achieve the required learning goals. In this way, the study goal of this column is removed, but the content of the learning goal has been further enriched, and its guidance has been strengthened. The original online test program is designed for students to conduct regular online testing. Network college each semester each of the main courses will have three to four times the test, the test is to give students a timely understanding of their own learning, timely correcting deviation may appear in the process of learning, let students always along the right track forward. Limited by the technology, the current Japanese professional class testing is still using the traditional written form, and the online test program has not been essentially applied. Therefore, in the design of the curriculum improvement, the online test section is deleted. New column Range Rover in Japan, with pictures and music to introduce background knowledge, some Japanese culture, customs and geography etc., and introduces some Japanese TV drama, for students to enjoy. Japan is divided into five sections: the range rover picture, pictures of Japan, Japanese songs, film and anime online hit. According to the requirement of each unit content arrangement and learning objectives, combined with the characteristics of language learning, according to the principle of the situational teaching method, the learning content is divided into above, speaking, reading and explain the three parts, each part of the vocabulary and grammar points to explain both in the form of two kinds of text and audio data into the corresponding situations, use text links. In addition, the text of the audio data after the split and the corresponding paragraph to link. In this way, students can access a difficult place, listen to unfamiliar words and sentences [5].

\section{Conclusion}

This research starts from the teaching practice of Japanese major in the network school, through investigation and analysis and in-depth interviews, to find out the present situation of Japanese network teaching, students' needs and teachers' expectation. Then, according to the principle of instructional design, the present curriculum has been improved from the content to the present form. Improved courseware by students after the trial of such feedback: the success of the course design should built in the full understanding of the needs of learners, learning environment, based on actual network teaching present situation, from the foreign language learning theory and foreign language teaching theory of adhering to the teaching system design concept, give full play to the advantages of network teaching resources are rich, as far as possible to make up for the online learning of defects in the communication and interaction.

\section{References}

[1] Xia Xia. Japanese language teaching. Heilongjiang science and technology information using multimedia. No. 05. (2013)

[2] Yang Yongbin. Principles and guidelines for the design of network courses in Colleges and universities. Computer knowledge and technology. No. 01. (2014)

[3] Li Dan. Multimedia courseware on the basis of zero in Japanese teaching application of. Science and Technology Consulting Herald. No. 16. (2012) 
[4] Lou Lou. Application of multimedia network technology in Japanese teaching. Chinese adult education. No. 03. (2011)

[5] Peng Ji. Multimedia courseware in Japanese Teaching in the application of. Technology in Neijiang. No. 01. (2012) 